\title{
Exposure Assessment of Pesticides to Farmers in Terms of Autoimmune System (Case Study: Farmers in Cibeureum Village, Kertasari District)
}

\author{
Kandina Rahmadita ${ }^{1}$ and Katharina Oginawati ${ }^{2}$ \\ Environmental Engineering, Institut Teknologi Bandung \\ Jl. Ganesha 10 Bandung 40132
}

\begin{abstract}
The use of pesticides certainly cannot be separated from agricultural activities to obtain resistantion from pest problems. However, most of farmers are not aware of toxic exposure caused by pesticides which led by inadequate knowledge of pesticide warehouse management within local farmers in Indonesia. This study aims to see dermal exposure concentration and the effect of pesticide exposure on farmworkers which is characterized by increasing of Antinuclear Antibody (ANA) level. This research was conducted on male farmers in Cibeureum Village, Kertasari District, Bandung Regency. For the control sample, conducted on organic farmers in Cisarua, Bogor. Dermal exposure sampling was taken to farmers in the morning when farmer do pesticide spraying activity, using pad sampling for dermal exposure. ANA test sampling for exposed farmers and control farmers do by certified laboratory. From this research founded that farmers exposed by organophosphate pesticide with active substance diazinon, fenitrothion, methidathion, malathion, chlorpyrifos, parathion, and profenofos with concentration ranged from $0-5,705 \mathrm{mg} / \mathrm{L}$ and carbamate pesticide with active substance carbofuran, MIPC, and BPMC with concentration ranged from $0-2,485 \mathrm{mg} / \mathrm{L}$. The concentration was converted to uptake accumulation and it was found that uptake was associated with pesticide concentration (correlation value between 0,484 0,731 with p-value near 0,000). From this study also obtained that uptake of diazinon, malathion, chlorpyrifos, and MIPC affect the increase of ANA levels of farmers in the blood due to continuous exposure over a long period of time.
\end{abstract}

Keywords: Antinuclear antibody (ANA), organophosphate, carbamate, autoimmune, dermal

\section{Introduction}

Evaluation of the chemicals toxic effects (including pesticides) are a major concern of public health, due to extensive use of pesticides for domestic and industrial purposes. There is a relationship between the Autoimmune Diseases (AID) with the use of pesticides. Research about relationship between autoimmune disease and exposure to pesticides now been started [1].

Pollard [2] mentions the existence of a positive association to the increase of Antinuclear Antibody (ANA) with long-term exposure to pesticides, ANA which have corelated with Autoimmune Diseases (AID). In Maulidiniawati and Oginawati [3] states that exposure to pesticides, organochlorine insecticides in particular, can cause chronic effects such as hypothyroidism. Based on Miller [4] hypothyroidism is associated with AID.

To determine the extent of the risks that can damage the health of farmers exposed to pesticides, we conducted a risk analysis study. One of the risks that arise from the use of these pesticides is the appearance of an autoimmune disease.

\section{Research Method}

This study was conducted in the Cibeureum village, Kertasari subdistrict, Bandung district to obtain a sample of exposed farmers. While the site to gain control sample is in the area of organic farming Cisarua, Bogor. The stages of research can be seen in Figure 1. 


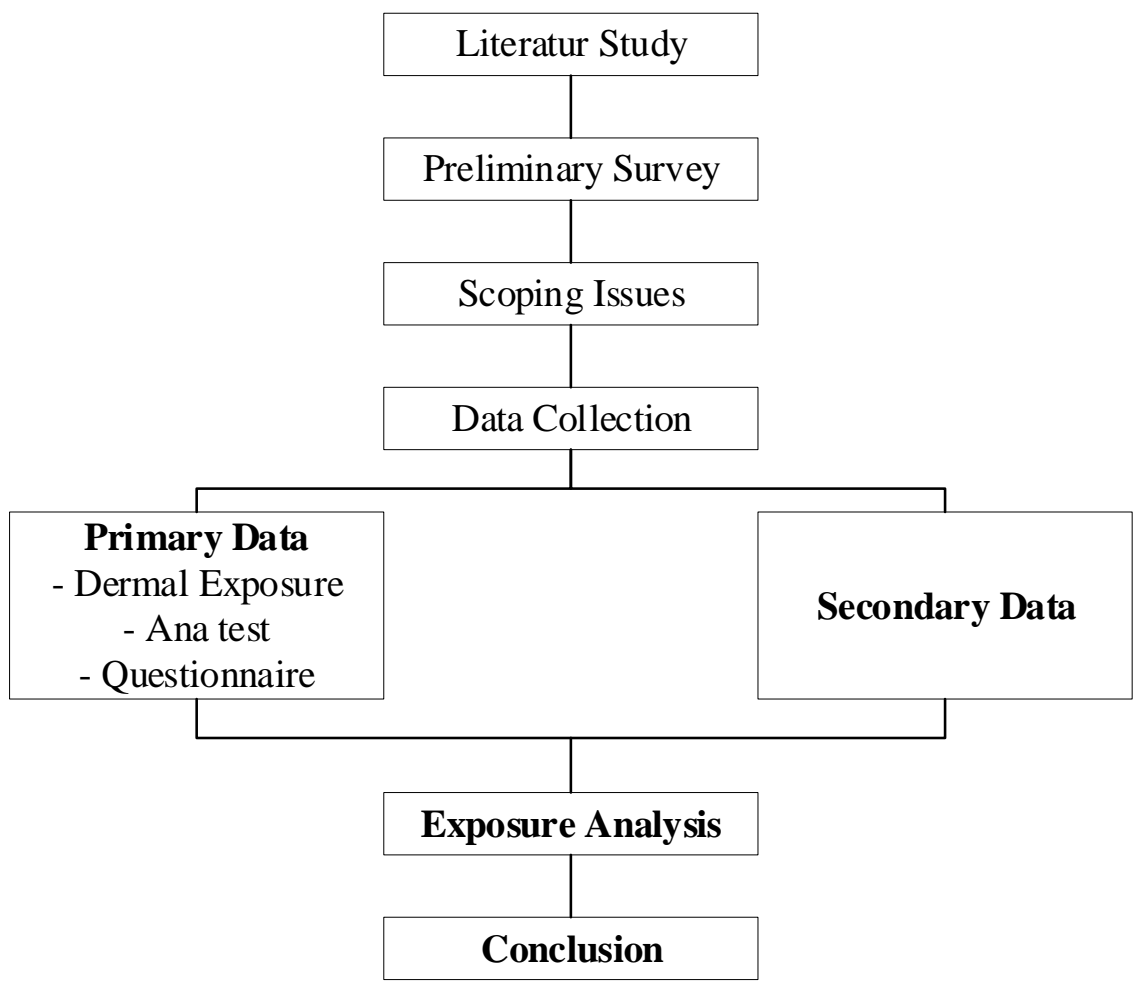

Fig. 1: Research Flowchart

\subsection{Population and Sample Research}

Number of exposed samples is 30 people, which is a sprayers farmer in the Cibeureum village. While the population controls used male farmers in organic farming in Cisarua, Bogor. Number of control samples is 9 people.

\subsection{Parameters}

The parameters which measured in this study consists of dermal pesticides exposure on the skin as well as the levels of antinuclear antibody (ANA) in the blood of exposed and control groups.

It also carried out measurements of physical parameters of the environment that includes air temperature, humidity, and wind speed. Also conducted interviews to exposed or spraying farmers to determine the general condition and habits of farmers.

\subsection{Exposure Analysis Method}

The analysis consists of pesticide exposure assessment activities in the dermal exposed samples. Methods to measure the dermal exposure of the dermal, is a method of Passive Dosimetry [5] or the pad method. Measurements conducted in the morning during spraying activities take place to get the real condition of dermal exposure to pesticides.

\subsection{Uptake Calculations}

Data obtained from the analysis of dermal exposure cannot directly used, so it needs to be converted into uptake using Equation 1 is based on US EPA (2001):

$$
\text { Dermal Absorbed Dose }(D A D)=\frac{D A_{\text {event }} \times E F \times E D \times E V \times S A}{B_{W} \times A_{T}}(\mathrm{mg} / \mathrm{kg}-\text { day })
$$

Description:

$\mathrm{DAD}=$ Dosage of pesticides enter the body (mg/ kg-day)

$\mathrm{DA}_{\text {event }}=$ Concentration of pesticides $\left(\mathrm{mg} / \mathrm{cm}^{2}\right.$ per one spraying)

$\mathrm{EF} \quad=$ Frequency of exposure (days/year)

$\mathrm{E}_{\mathrm{D}} \quad=$ Duration of exposure (hours) 
EV = Spraying frequency every day (events/day)

SA $=$ Area of skin surface is available for contact $\left(\mathrm{cm}^{2}\right)$

$\mathrm{B}_{\mathrm{w}} \quad=$ Weight $(\mathrm{kg})$

$\mathrm{A}_{\mathrm{T}} \quad=$ The average time (hours/day)

\subsection{Data Analysis}

Cross-sectional epidemiological studies are used in this study to see the effects of pesticide exposure on the farmer's health. ANA abnormal levels indicate Autoimmune disorder (AID). Given health effects resulting from exposure to pesticides are chronic in the long term which is characterized by an increase in ANA in the blood. Health measurement is done simultaneously to see the impact of farming and the length of time of exposure to elevated levels of ANA in the blood of farmers spraying.

The data were analyzed to test the hypothesis using a statistical test using descriptive statistics and correlation analysis.

\section{Result and Discussion}

\subsection{Hazard Identification}

Preliminary test results of sample analysis in the form of pesticides used by farmers in the village Cibeureum, found that there are organophosphate and carbamate pesticides in a mixture of pesticides used by farmers.

When the class of organophosphate pesticides enter the body, it will bind to the enzyme cholinesterase in the blood that controls the nerves work and can make the enzyme can perform its function, so that the nerves in the body continues to send commands to a particular muscle to keep moving out of control. How to work together with a group of carbamate pesticide organophosphate that inhibits the action of the enzyme cholinesterase. Effect of carbamate pesticides on cholinesterase enzyme was brief, because carbamate pesticides immediately decomposes in the body.

ANA value measurements were also conducted on organic farmers. It is intended to compare the value of the ANA between farmers exposed and not exposed to organophosphate and carbamate pesticides. ANA measurement results can be seen in Figure 2 below.

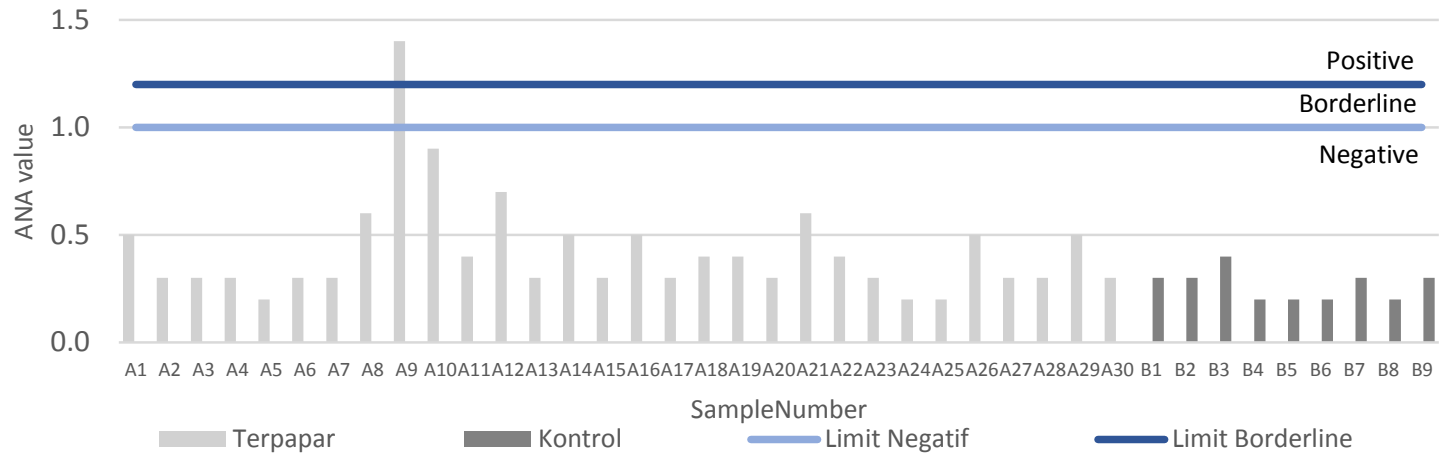

Fig. 2: Distribution of value ANA

Reference value for ANA in the blood is < 1 . If the value of ANA someone exceeds 1, it can be said that the farmers indicated autoimmune disease. Statistical analysis showed $p$-value of $0,011(\mathrm{p}<0,05)$, which states that the average ANA value of the exposed and control groups were significantly different (unequal).

\subsection{Exposure Analysis}

Based on the measured data of physical parameters of the environment in Table 1, it can be seen that the air temperature air temperature standards in the agricultural environment. Wind speed was below standard, resulting 
in high concentrations of pesticide source so that it would be potentially harmful to farmers sprayers. As for the low air humidity, can make the pesticide evaporates quickly and can reduce the concentration of pesticide to absorbed [6].

TABLE 1: Parameters of Physical Environment, Kartasapoetra [7]

\begin{tabular}{ccc}
\hline \hline Parameters & Value & Threshold \\
\hline Air Temperature $(\mathrm{C})$ & $17,88 \pm 0,34$ & $18-30$ \\
Air Humidity $(\%)$ & $64,1 \pm 7,56$ & $65-95$ \\
Wind Speed $(\mathrm{km} / \mathrm{h})$ & $8,25 \pm 0,41$ & $19-35$ \\
\hline \hline
\end{tabular}

Based on the analysis of exposure, it was found that the composition of mixtures of pesticides used by farmers in the village are the types of organophosphates Cibeureum diazinon, fenitrotion, metidation, malathion, chlorpyrifos, paration, and profenofos and carbamate type of carbofuran, MIPC, and BPMC. This can be due to the similarity of trademarks pesticides used by the majority of farmers who are growers of potatoes, leeks, and cabbage.

TABLE 2: Pesticides exposure uptake

\begin{tabular}{|c|c|c|c|c|c|}
\hline \multirow{2}{*}{ Uptake } & \multicolumn{5}{|c|}{ Uptake (mg/kg-day) } \\
\hline & \multicolumn{3}{|c|}{ Average } & \multirow{3}{*}{$\begin{array}{l}\text { Min } \\
0,181\end{array}$} & \multirow{3}{*}{$\begin{array}{l}\text { Max } \\
5.957\end{array}$} \\
\hline Organofosfat & & & & & \\
\hline Diazinon & 0,312 & \pm & 0,957 & & \\
\hline Fenitrotion & 0,040 & \pm & 0,142 & 0,310 & 0,706 \\
\hline Metidation & 3,200 & \pm & 5,121 & 0,180 & 22,877 \\
\hline Malation & 0,236 & \pm & 0,419 & 0,206 & 1,878 \\
\hline Klorpirifos & 4,277 & \pm & 5,705 & 0,264 & 26,997 \\
\hline Paration & 0,442 & \pm & 0,380 & 0,197 & 1,382 \\
\hline Profenofos & 0,368 & \pm & 0,624 & 0,176 & 2,705 \\
\hline \multicolumn{6}{|l|}{ Karbamat } \\
\hline Karbofuran & 0,060 & \pm & 0,229 & 0,238 & 1,203 \\
\hline MIPC & 0,153 & \pm & 0,221 & 0,222 & 0,621 \\
\hline BPMC & 0,213 & \pm & 0,394 & 0,132 & 1,676 \\
\hline
\end{tabular}

From Table 2 gained an average uptake of exposure to pesticides derived from the active ingredient chlorpyrifos is equal to $4,277 \pm 5,705 \mathrm{mg} / \mathrm{kg}$-day. Uptake is influenced by specific factors of skin (skin temperature and age) as well as the specific factors of the components of pesticides (pesticide concentration) [6]. Uptake correlation of test results with age, skin temperature, and the concentration of pesticides, found that the concentration-related and significant impact on the increase in the value of uptake of pesticides. Correlation value against the uptake of pesticide concentrations near 1 (the strong relationship) and the significant value of $\mathrm{p}$ $<0,05$.

Many factors affect the value of ANA. Determination of the factors that affect the magnitude of pesticides impact is important to note. Determining factors are aiming to get a real relationship between the concentration of pesticide exposure to human impact is included in order to discover solutions of impact prevention [8]. In this study, a factor that is observed is the uptake of organophosphat and carbamate pesticides in the body's absorption of farmers, working experience, age, nutritional status (BMI) and smoking habits. 
TABLE 3: Results of correlation internal factors with exposed group ANA value

\begin{tabular}{ccc}
\hline \hline Factors & Correlation & p-value \\
\hline Working experience & 0,013 & 0,946 \\
Age & $-0,054$ & 0,775 \\
BMI & 0,083 & 0,664 \\
Smoking Habit & $-0,038$ & 0,841 \\
\hline \hline
\end{tabular}

Table 3 shows that working experience and BMI was positively related to an increase of ANA value to exposed group but weak (value of correlation approaches 0 ) and not significant ( $p>0,05)$. While age and smoking habits have a negative correlation to the increase in the value of the ANA but weak (value of correlation approaches 0$)$ and not significant $(\mathrm{p}>0,05)$.

TABLE 4: Results of correlation internal factors with control group ANA value

\begin{tabular}{ccc}
\hline \hline Factors & Correlation & p-value \\
\hline Working experience & 0,473 & 0,199 \\
Age & 0,361 & 0,069 \\
BMI & 0,033 & 0,933 \\
Smoking Habit & $-0,624$ & 0,073 \\
\hline \hline
\end{tabular}

Table 4 shows that work experience, age and BMI was positively related to an increases ANA value in control group but not significant $(\mathrm{p}>0,05)$. While smoking has a negative correlation to the increase in the value of ANA and not significant $(\mathrm{p}>0,05)$.

TABLE 5: The results of correlation ANA value with pesticide uptake

\begin{tabular}{lcc}
\hline \hline \multicolumn{1}{c}{ Uptake } & Correlation & p-value \\
\hline Organofosfat & & \\
\hline Diazinon & 0,731 & 0,000 \\
Fenitrotion & 0,021 & 0,911 \\
Metidation & 0,205 & 0,277 \\
Malation & 0,489 & 0,006 \\
Klorpirifos & 0,679 & 0,000 \\
Paration & 0,336 & 0,069 \\
Profenofos & 0,012 & 0,950 \\
\hline Karbamat & & \\
\hline Karbofuran & 0,112 & 0,557 \\
MIPC & 0,484 & 0,007 \\
BPMC & 0,161 & 0,396 \\
\hline \hline
\end{tabular}

It can be seen from Table 5 that uptake of organophosphates and carbamates have the closest correlation with the increase in the value of ANA in the blood of farmers spraying is diazinon with a value of $0,731(\mathrm{p}=$ $0,000)$, chlorpyrifos with a value of $0,679(\mathrm{p}=0,000)$, malathion with value $0,489(\mathrm{p}=0,006)$, and the MIPC and carbamates with a value of $0,484(\mathrm{p}=0,007)$. This figure reflects the real relationship given by diazinon, chlorpyrifos, malathion, and MIPC to the increase in the child, while the uptake of the active substance does not provide a strong correlation and no significant effect on the increase in the value of ANA in the blood of farmers spraying.

\subsection{Conclusion}

Organophosphate and carbamate pesticides give a chronic effects to people whom exposed. Chronic effects seen in this study is a disorder of the autoimmune system by increasing the value of ANA in the blood. Based on this research, the most influential factor in the accumulation of uptake in the body of farmers is the concentration of exposure to pesticides diazinon amounted to 0,999 , fenitrotion at 0,970 , metidation at 0,989 , malathion at 0,961 , chlorpyrifos at 0,987 , paration of 0,947 , profenofos at 0,986 , carbofuran at 0,977 , MIPC amounted to 
0,980, and BPMC at 0,988. While the factors that affect the increase in the value of ANA in the blood of farmers is uptake value diazinon, malathion, chlorpyrifos, and MIPC (significance $p<0,05$ ). Increasing the value of the ANA is an indicator of the occurrence of AID, thus it can be concluded from this study that is based on a statistical test uptake diazinon, malathion, chlorpyrifos, and MIPC significantly associated with an increase in the value of ANA is a marker of the beginning of the chronic effects, namely the emergence of AID. To prevent an increases the ANA value to farmers sprayers, it is suggested that farmers can stop the use of synthetic pesticides (organophosphates and carbamates) and start using pesticides from natural ingredients.

\section{References}

[1] Vial. T., Nicolas. B., dan Descotes. J. (2011): Clinical Immunotoxicity of Pesticides. Juornal of Toxicology and Environmental Health. Volume 48, 1996 - Issue 3. Pages 215-229

[2] Pollard, Kenneth Michael. 2012. Gender Differences in Autoimmunity Associated with Exposure to Environmental Factors. J Autoimmune. 2012 May; 38 (2-3): JI77-JI86.

https://doi.org/10.1016/j.jaut.2011.11.007

[3] Maulidiniawati, Nurika., dan Oginawati, Katharina. 2013. Paparan Dermal dan Efek Kronis Insektisida Organoklorin Terhadap Gangguan Tiroid Pada Petani Penyemprot di Kecamatan Kertasari Kabupaten Bandung. Jurnal Teknik Lingkungan. 7-1 - 7-10

[4] Miller, Frederick W., Alfredsson, Lars., Costenbader, Karen H., Kamen, Diane L., Nelson, Lorene., Norris, Jill M., dan De Roos, Anneclaire J. 2012. Epidemiology of Encironmental Exposures and Human Autoimmune Diseases: Finding from a National Institute of Environmental Health Sciences Expert Panel Workshop. National Institute of Health. J Autoimmun. 2012 December;39(4):259-271 https://doi.org/10.1016/j.jaut.2012.05.002

[5] Oginawati, Katharina. (2005): Analisis Risiko Penggunaan Insektisida Organofosfat terhadap Kesehatan Petani Penyemprot. Disertasi Doktor. Institut Teknologi Bandung

[6] US EPA. 2001. Supplemental Guidance for Dermal Risk Assessment. Human Health Evaluation Manual. United States Environmental Protection Agency. Vol. 1: Part E.

[7] Kartasapoetra, Ance Gunarsih. (1993): Klimatologi: Pengaruh Iklim Terhadap Tanah Dan Tanaman. Bumi Aksara. Jakarta.

[8] Greitens, Thomas J., Day, Esther. (2007): An alternative way to evaluate the environmental effects of integrated pest management: Pesticide risk indicators. Renewable Agriculture and Food Systems Volume 22, Issue 3 pp. 213-222. https://doi.org/10.1017/S1742170507001755 